\title{
Gambaran Pengetahuan Ibu Hamil Tentang Isi Buku KIA di klinik Ramuah Parjib Kota Samarinda Tahun 2020
}

\author{
Andi Fawiloy ${ }^{1}$, Vistra Veftisia ${ }^{2}$ \\ 1,2 Program Studi Kebidanan Program Sarjana, Universitas Ngudi Waluyo Ungaran \\ Email : andifa1451@gmail.com, vistravef@gmail.com
}

\begin{abstract}
ABSTRAK
Jumlah AKI (Angka Kematian Ibu) di Indonesia masih tergolong tinggi jika dibandingkan dengan Negara Asia Tenggara lainnya. Salah Satu Program pemerintah dalam menurunkan AKI yaitu pemberian Buku KIA pada Setiap ibu hamil. Hasil dari studi pendahuluan yang dilakukan di Klinik Ramlah Parjib Kota Samarinda pada 10 ibu hamil didapatkan bahwa 4 responden mengetahui tentang tanda bahaya kehamilan. 4 orang responden lainnya tidak mengetahui tentang pemeriksaan kehamilan secara teratur, dan perawatan kehamilan sehari-hari serta makanan pada ibu hamil, dan 2 responden sama sekali tidak dapat menyebutkan tanda bahaya kehamilan, pemeriksaan kehamilan secara teratur dan perawatan kehamilan sehari-hari serta makanan ibu hamil. Tujuan dari penelitian ini yaitu untuk mengetahui Gambaran Pengetahuan Ibu Hamil tentang isi Buku KIA di Klinik Ramlah Parjib Kota Samarinda Tahun 2020. Jenis penelitian Deskriptif kuantitatif dengan rancangan penelitian Cross Sectional. Jumlah Populasi 118 dan jumlah sampel 43 responden, menggunakan teknik accidental sampling. Instrumen penelitian menggunakan kuesioner, dan analisis data menggunakan Analisis Univariat frekuensi dan persen. Hasil Penelitian didapatkan pengetahuan Ibu Hamil tentang pemeriksaan kehamilan secara teratur sebagian besar dalam kategori cukup yaitu sebanyak 33 responden (76,7\%), Tanda Bahaya Pada Kehamilan sebagian besar dalam kategori baik sebanyak 33 responden (76,7\%), Perawatan Sehari-hari Ibu Hamil dan Porsi Makanan Ibu Hamil sebagian besar dalam kategori baik sebanyak 38 responden $(88,4 \%)$. Simpulan Gambaran Pengetahuan Ibu Hamil tentang Isi Buku KIA di Klinik Ramlah Paijib Kota Samarinda sebagian besar dalam kategori baik yaitu sebanyak 30 responden $(69,8)$, Diharapkan tenaga kesehatan perlu memberikan informasi tentang Pemeriksaan kehamilan secara teratur pada ibu hamil dan membaca isi buku KIA.
\end{abstract}

\section{Kata Kunci : Pengetahuan Buku KIA}

\begin{abstract}
ABSTRACK
An overview of pregnant women's knowledge about the contents of the MCH handbook at the Ramuah Parjib clinic, Samarinda City in 2020

The number of MMR (Thu Mortality Rate) in Indonesia is still relatively high when compared to other Southeast Asian countries. One of the government's programs in reducing MMR is the provision of MCH Handbooks to every pregnant woman. The results of a preliminary study conducted at the Ramlah Parjib Clinic, Samarinda City on 10 pregnant women, it was found that 4 respondents knew about the danger signs of pregnancy. The other 4 respondents did not know about regular pregnancy checkups, and daily prenatal care and food for pregnant women, and 2 respondents
\end{abstract}

Gambaran Pengetahuan Ibu... Andi Fawiloy, Vistra Veftisia Journal of Holistics and Health Sciences Vol. 3, No. 2 September 2021 
could not at all mention the danger signs of pregnancy, regular pregnancy checkups and daily prenatal care and food for pregnant women. The purpose of this study was to find out the Description of Pregnant Women's Knowledge about the contents of the MCH Handbook at the Ramlah Parjib Clinic, Samarinda City in 2020. The type of research is quantitative descriptive with a cross sectional research design. The total population is 118 and the sample size is 43 respondents, using accidental sampling technique. The research instrument used a questionnaire, and data analysis used Univariate analysis offrequency and percent. The results showed that the knowledge of pregnant women about regular pregnancy check-ups was mostly in the sufficient category, namely 33 respondents (76.7\%), the danger signs in pregnancy were mostly in the good category, as many as 33 respondents (76.7\%), daily care Pregnant women and the portion of food for pregnant women are mostly in the good category as many as 38 respondents (88.4\%). Conclusion Description of Pregnant Women's Knowledge of the Contents of the MCH Handbook at the Ramlah Paijib Clinic, Samarinda City, mostly in the good category, as many as 30 respondents (69.8). It is expected that health workers need to provide information about regular pregnancy check-ups for pregnant women and read the contents of the book KIA

\section{Keywords: KIA book knowledge}

\section{PENDAHULUAN}

Kehamilan dan persalinan merupakan proses yang alamiah dan pasti akan dialami setiap wanita. Perubahan-perubahan yang teijadi pada wanita selama kehamilan adalah bersifat fisiologis bukan patologis (Manuaba, 2014). masalah utama yang sering kali dihadapi dalam maternal care adalah masih tingginya Angka Kematian Ibu (AKI) dan Angka Kematian Bayi (AKB). Hal ini merupakan salah satu masalah yang serius (Depkes, 2012).

Menurut WHO (2014) AKI di Dunia mencapai angka 289.000 jiwa dimana dibagi atas beberapa negara antara lain Amerika Serikat mencapai 9300 jiwa, Afrika Utara 179.000 jiwa dan Asia Tenggara 16.000 jiwa. AKI di Negara-negara Asia Tenggara seperti Malaysia $\quad(39 / 100.000$ kelahiran hidup), Thailand (44/100.000 kelahiran hidup), Fhilipina (170/100.000 kelahiran hidup), Brunei Darussalam (60/100.000 kelahiran hidup),
Vietnam (160/100.000 kelahiran hidup), serta Singapura (3/100.000 kelahiran hidup). Jumlah AKI di Indonesia masih tergolong tinggi jika dibandingkan dengan Negara Asia Tenggara lainnya.

Menurut Profil Kesehatan Indonesia (2019), Pada tahun 1994 kasus kematian ibu sebanyak 390/100.000 KH, tahun 1997 sebanyak 334/100.000 KH, tahun 2002 sebanyak 307/100.000 KH, tahun 2007 sebanyak 228/100.000, tahun 2012 meningkat menjadi $359 / 100.000 \mathrm{KH}$, dan pada tahun 2015-2019 AKI mengalami penurunan kembali sebanyak 305/100.000 KH. Walaupun AKI sudah menurun namun angka ini masih menunjukkan negara indonesia termasuk negara AKI yang terbanyak di ASEAN.

Data Dinas Provinsi KalimantanTimur (2016) diperoleh data AKI setiap tahunnya mengalami penurunan pada tahun 2013 sebanyak 133/100.000 KH, tahun 2014 menjadi 
104/100.000 KH, dan pada tahun 2015 menjadi 100/ 100.000 KH. Dan pada tahun 2016 menjadi 95/100.00 $\mathrm{KH}$.

Data AKI Kota Samarinda pada tahun 2016 terdapat kasus kematian sebanyak 40 per $100.000 \mathrm{KH}$. pada tahun 2015 data AKI yang ada di kota Samarinda yaitu sebanyak 76 per $100.000 \mathrm{KH}$. Jika dilihat dari data yang ada teijadi penurunan yang signifikan yaitu sebanyak 36 kasus dari 76 per $100.000 \mathrm{KH}$ (Dinas Kesehatan Provinsi Kalimantan Timur, 2016).

Progran pemerintah dalam menurunkan AKI yaitu memberikan pelayanan kesehatan ibu hamil, pelayanan imunisasi Tetanus bagi wanita usia subur dan ibu hamil, pemberian tablet tambah darah, pelayanan kesehatan ibu bersalin, pelayanan kesehatan ibu nifas, Puskesmas melaksanakan kelas ibu hamil dan Program Perencanaan Persalinan dan Pencegahan Komplikasi (P4K), pelayanan kontrasepsi/KB dan pemeriksaan HIV, Hepatitis B dan pemberian Buku Kesehatan Ibu dan Anak (KIA) pada setiap ibu hamil (Profil Kesehatan Indonesia, 2019).

Secara garis besar manfaat buku KIA dapat dibagi menjadi dua yaitu manfaat umum dan khusus. Manfaat buku KIA secara umum yaitu ibu dan anak mempunyai catatan kesehatan yang lengkap. Sedangkan Manfaat secara khusus terdapat 4 manfaat yaitu : untuk mencatat dan memantau kesehatan ibu dan anak, sebagai alat komunikasi dan penyuluhan yang dilengkapi dengan informasi penting bagi ibu, keluarga dan masyarakat tentang standar pelayanan KIA, Sebagai alat untuk mendeteksi secara dini adanya gangguan atau masalah kesehatan ibu dan anak, dan sebagai catatan pelayanan gizi dan kesehatan ibu dan anak termasuk rujukannya (Depkes, 2015).

Studi pendahuluan yang telah dilakukan pada bulan Oktober 2020 di Klinik Ramlah Paijib dengan wawancara dan observasi pada $10 \mathrm{ibu}$ hamil didapatkan bahwa 4 responden dapat menyebutkan mengenai tanda bahaya kehamilan yaitu kaki bengkak, dan kepala pusing. 4 orang responden tidak mengetahui tentang pemeriksaan kehamilan secara teratur, dan perawatan kehamilan sehari-hari serta makanan pada ibu hamil, 2 responden sama sekali tidak bisa menyebutkan tanda bahaya kehamilan, pemeriksaan kehamilan secara teratur dan perawatan kehamilan sehari-hari serta makanan pada ibu hamil.

Hasil observasi pada ibu hamil yang melakukan kunjungan antenatal care, setiap ibu hamil yang baru datang dan belum memiliki buku KIA maka petugas kesehatan khususnya bidan jaga memberikan buku KIA. Hanya saja karena waktu yang terbatas sehingga bidan jaga jarang menjelaskan isi buku KIA secara menyeluruh dan jarang menganjurkan ibu hamil untuk membaca isi buku KIA yang didapat kecuali ibu hamil yang memiliki keluhan maka akan dijelaskan mengenai isi buku KIA sesuai dengan keluhan.

\section{METODE}

Jenis Penelitian yang digunaka dalam penelitian ini adalah deskriptif kuantitatif dengan pendekatan Cross Sectional. Populasi dalam penelitian ini adalah Ibu Hamil yang memeriksakan kehamilannya ke Klinik Ramlah Paijib pada bulan Oktober tahun 2020 yaitu 118 responden. Teknik pengambilan sampel menggunakan teknik 
accidental sampling, dengan jumlah sampel 43 responden. Pengumpulan data menggunakan kuesioner dan analisis data menggunakan analisis univariat dengan menggunakan distribusi frekuensi

\section{HASIL DAN PEMBAHASAN}

\section{Hasil}

1. Gambaran Pengetahuan Ibu Hamil Tentang Pemeriksaan Kehamilan Secara teratur

Tabel 1 Distribusi Frekuensi Pengetahuan Ibu Hamil Tentang Pemeriksaan Kehamilan Secara teratur di Klinik Ramlah Parjib Kota Samarinda

\begin{tabular}{lcc}
\hline $\begin{array}{l}\text { Pemeriksaan Kehamilan } \\
\text { Secara Teratur }\end{array}$ & Frekuensi & Presentase (\%) \\
\hline Kurang & 8 & 18,6 \\
Cukup & 33 & 76,7 \\
Baik & 2 & 4,7 \\
\hline Jumlah & 43 & 100,0 \\
\hline
\end{tabular}

Berdasarkan tabel 1 menunjukkan bahwa pengetahuan ibu tentang pemeriksaan kehamilan secar teratur sebagian besar dalam kategori cukup yaitu sebanyak 33 responden $(76,7 \%)$ dan sebagian kecil memiliki pengetahuan baik sebanyak 2 responden $(4,7 \%)$

Tabel 2 Distribusi Jawaban Responden Tentang Pemeriksaan Kehamilan Secara Teratur di Klinik Ramlah Parjib Kota Samarinda

2. Pengetahuan Ibu Hamil Tentang Tanda Bahaya Pada Kehamilan

\begin{tabular}{|c|c|c|c|c|c|}
\hline No & Pernyataan & Benar & $\%$ & Salah & $\%$ \\
\hline & $\begin{array}{l}\text { Pemeriksaan Kehamilan Secara } \\
\text { Teratur }\end{array}$ & & & & \\
\hline 1. & $\begin{array}{l}\text { Kunjungan ibu hamil dilakukan } \\
\text { paling sedikit } 6 x \text { selama masa } \\
\text { kehamilan }\end{array}$ & 32 & 74,4 & 11 & 25,6 \\
\hline 2. & $\begin{array}{l}\text { Kunjungan ibu hamil selama } \\
\text { trimester pertama }(0-3 \text { bulan }) \\
\text { dilakukan paling sedikit } 1 \mathrm{x}\end{array}$ & 4 & 9,3 & 39 & 90,7 \\
\hline 3. & $\begin{array}{l}\text { Kunjungan ibu hamil trimester } \\
\text { kedua ( } 4-7 \text { bulan) dilakukan paling } \\
\text { sedikit } 2 x\end{array}$ & 10 & 23,3 & 33 & 76,7 \\
\hline 4. & $\begin{array}{l}\text { Pada trimester ketiga ( } 7-9 \text { bulan }) \\
\text { kunjungan ibu hamil dilakukan } \\
\text { paling sedikit } 3 \text { kali }\end{array}$ & 33 & 76,7 & 10 & 23,3 \\
\hline 5. & $\begin{array}{l}\text { Pemeriksaan kehamilan yang } \\
\text { pertama kali sebaiknya dilakukan } \\
\text { sesegera mungkin setelah diketahui } \\
\text { terlambat haid }\end{array}$ & 42 & 97,7 & 1 & 2,3 \\
\hline 6. & $\begin{array}{l}\text { Pemeriksaan berat badan pada ibu } \\
\text { hamil harus dilakukan untuk } \\
\text { mengetahui kenaikan berat badan } \\
\text { ibu sebelum dan saat hamil }\end{array}$ & 41 & 95,3 & 2 & 4,7 \\
\hline
\end{tabular}

Distribusi Frekuensi Pengetahuan Ibu Hamil Tentang Isi Buku KIA Tanda Bahaya Pada Kehamilan di Klinik Ramlah Parjib Kota Samarinda 
7.

Pemeriksaan tekanan darah pada ibu hamil hanya dilakukan pada ibu hamil dengan riwayat tekanan darah tinggi

8. Pemeriksaan laboratorium dilakukan hanya pada ibu hamil dengan keluhan
$34 \quad 79,1 \quad 9 \quad 20,9$

$32 \quad 74,4 \quad 11 \quad 25,6$

Tanda Bahaya

$\begin{array}{lll}\text { Kehamilan } & \text { Frekuensi } & \text { Presentase (\%) }\end{array}$

\begin{tabular}{lcc} 
Kurang & 5 & 11,6 \\
Cukup & 5 & 11,6 \\
Baik & 33 & 76,7 \\
\hline Jumlah & 43 & 100,0 \\
\hline
\end{tabular}

Berdasarkan tabel 3 kategori baik yaitu sebanyak 33 menunjukkan bahwa pengetahuan responden (76,7\%) dan ibu tentang Tanda Bahaya Pada pengetahuan kurang sebanyak 5 Kehamilan sebagian besar dalam responden $(11,6 \%)$.

Tabel 4 Distribusi Jawaban Responden Tanda Bahaya Pada Kehamilan di Klinik

Ramlah Parjib Distribusi Jawaban Responden Tentang Isi Buku KIA

No $\quad$ Pernyataan $\quad$ Benar $\%$ Salah $\%$

9. $\quad$ Perdarahan melalui jalan lahir pada kehamilan dapat membahayakan ibu dan janin

10. Ibu hamil yang Muntah terus menerus dan tidak mau makan akan menganggu perkembangan dan pertumbuhan janin

11 Ibu hamil yang mengalami bengkak pada kaki, tangan, wajah dan tidak hilang setelah beristirahat akan membahayakan ibu dan janin

12 Gerakan janin yang kurang dari 10x dalam sehari merupakan tanda bahwa janin sedang beristirahat

13. Keluarnya cairan yang berbau khas amis sebelum waktunya melahirkan merupakan hal yang biasa teijadi pada ibu hamil

14. Ibu hamil yang mengalami demam tinggi $>38^{\circ} \mathrm{C}$ dapat meningkatkan resiko kelainan pada janin seperti cacat

15.

Pandangan kabur secara mendadak pada ibu hamil akan mempengaruhi kesehatan ibu dan janin

16.

Ibu hamil wajib memeriksakan diri

$43 \quad 100 \quad 0 \quad 0$

$\begin{array}{llll}38 & 88,4 & 5 & 11,6\end{array}$

$38 \quad 88,4 \quad 5 \quad 11,6$

$28 \quad 65,1 \quad 15 \quad 34,9$

$\begin{array}{llll}36 & 83,7 & 7 & 16,3\end{array}$

kepetugas kesehatan apabila ada tanda-tanda yang membahayakan 
Ibu hamil disarankan minum air putih lebih dari 2 liter setiap harinya

3. Pengetahuan Ibu Hamil Tentang Perawatan Sehari-hari Ibu Hamil dan Porsi Makanan Ibu Hamil

Tabel 5 Distribusi Frekuensi Pengetahuan Ibu Hamil Tentang Isi Buku KIA Perawatan Sehari-hari Ibu Hamil dan Porsi Makan

\begin{tabular}{lll}
\hline $\begin{array}{l}\text { Perawatan Seharihari } \\
\text { dan Porsi Makanan Ibu }\end{array}$ & Frekuensi & Presentase (\%) \\
Hamil & \\
\hline
\end{tabular}

\begin{tabular}{lcc}
\hline Kurang & 0 & 0 \\
Cukup & 5 & 11,6 \\
Baik & 38 & 88,4 \\
\hline Jumlah & 43 & 100,0 \\
\hline
\end{tabular}

$\begin{array}{lrlr}\text { Berdasarkan } & \text { tabel } 5 & & \text { besar dalam kategori baik yaitu } \\ \text { menunjukkan } & \text { bahwa } & \text { sebanyak } 38 & \text { responden } \\ \text { pengetahuan ibu tentang isi } & (88,4 \%) \text { dan pengetahuan } \\ \text { buku KIA Perawatan Sehari- } & \text { cukup sebanyak } 5 \text { responden } \\ \text { hari Ibu Hamil dan Porsi } & (11,6 \%) .\end{array}$

Makanan Ibu Hamil sebagian

Tabel 6 Distribusi Jawaban Responden Tentang Isi Buku KIA Perawatan Seharihari Ibu Hamil Dan Porsi Makanan Ibu Hamil di Klinik Ramlah Parjib Kota

\begin{tabular}{|c|c|c|c|c|c|}
\hline \multicolumn{6}{|c|}{ Samarinda } \\
\hline No. & Pernyataan & Benar & $\%$ & Salah & $\%$ \\
\hline & $\begin{array}{l}\text { Perawatan Sehari-hari Ibu } \\
\text { Hamil }\end{array}$ & & & & \\
\hline & $\begin{array}{l}\text { Ibu hamil sebaiknya makan } \\
\text { porsinya lebih banyak dari } \\
\text { sebelum hamil }\end{array}$ & 31 & 72,1 & 12 & 27,9 \\
\hline & $\begin{array}{l}\text { Ibu hamil tidur malam } \\
\text { sebaiknva 6-7 iam }\end{array}$ & 34 & 79,1 & 9 & 20,9 \\
\hline 20. & $\begin{array}{l}\text { Ibu hamil perlu beristirahat pada } \\
\text { siang hari } 1-2 \text { iam }\end{array}$ & 41 & 95,3 & 2 & 4,7 \\
\hline 21. & $\begin{array}{l}\text { Ibu hamil sebaiknya tidur miring } \\
\text { kesebelah kiri agar asupan } \\
\text { oksigen lancar ke janin }\end{array}$ & 42 & 97,7 & 1 & 2,3 \\
\hline & $\begin{array}{l}\text { Ibu hamil disarankan keramas / } \\
\text { cuci rambut lebih dari } 2 \text { hari } \\
\text { sekali dalam seminggu }\end{array}$ & 18 & 41,9 & 25 & 58,1 \\
\hline 23. & $\begin{array}{l}\text { ibu hamil disarankan makan } \\
\text { sayur- sayuran dan buah-buahan } \\
\text { pada saat masa kehamilan }\end{array}$ & 43 & 100 & 0 & 0 \\
\hline & $\begin{array}{l}\text { Ibu hamil disarankan makan } \\
\text { protein yang cukup seperti ikan, } \\
\text { telur, dan daging }\end{array}$ & 43 & 100 & 0 & 0 \\
\hline 25. & $\begin{array}{l}\text { Ibu hamil dapat mengonsumsi } \\
\text { makanan dan minuman yang } \\
\text { mengandung banyak gula } \\
\text { sesering mungkin }\end{array}$ & 37 & 86,0 & 6 & 14,0 \\
\hline
\end{tabular}


1. Gambaran pengetahuan Ibu Hamil Tentang Isi Buku KIA di Klinik Ramlah Paijib Kota Samarinda

Tabel 7 Distribusi Frekuensi Pengetahuan Ibu Hamil Tentang Isi Buku KIA di Klinik Ramlah Parjib Kota Samarinda

\begin{tabular}{lcc}
\hline $\begin{array}{l}\text { Pengetahuan tentang Isi } \\
\text { Buku KIA }\end{array}$ & Frekuensi & Presentase (\%) \\
\hline Kurang & 0 & 0 \\
Cukup & 13 & 30,2 \\
Baik & 30 & 69,8 \\
\hline Jumlah & 43 & 100,0 \\
\hline
\end{tabular}

Hasil penelitian menunjukkan sebagian besar responden memiliki pengetahuan baik tentang isi buku KIA sebanyak 30 responden $(69,8)$, dan sebagian kecil responden memiliki pengetahuan cukup sebanyak 13 responden $(30,2 \%)$.

\section{PEMBAHASAN}

1. Gambaran Pengetahuan Ibu Hamil Tentang Pemeriksaan Kehamilan Secara teratur Hasil penelitian sebagian besar responden memiliki pengetahuan cukup tentang pemeriksaan kehamilan secara teratur yaitu sebanyak 33 responden $(76,7 \%)$. Sesuai hasil kuesioner responden banyak menjawab penyataan salah terdapat pada pernyataan nomor 2 sebanyak 30 responden $(90,90 \%)$ dengan pernyataan "Kunjungan ibu hamil selama trimester pertama (0-3 bulan) dilakukan paling sedikit $1 x$ ". Seharusnya kunjungan ibu hamil pada trimester pertama dilakukan sebanyak $2 \mathrm{x}$ selama masa kehamilan hal ini dikarenakan adanya pandemi covid-19 sehingga pemeriksaan kehamilan diganti menjadi $2 \mathrm{x}$ selama kehamilan tujuannya untuk mendeteksi faktor resiko penularan covid-19. Hal ini sesuai dengan Teori Depkes RI \& JICA (2020) yang mengatakan bahwa kunjungan ibu hamil pada trimester pertama dilakukan sebanyak 2x selama masa kehamilan.. Berdasarkan Teori POKJA (2020) menyatakan bahwa pemeriksaan antenatal selama kehamilan dianjurkan minimal 6x tatap muka tanpa melihat status zona covid-19 daerah tersebut dan dapat ditambahkan pemeriksaan telemedicine sesuai kebutuhan. Pemeriksaan pertama kali pada trimester I yaitu skrining faktor resiko dan gejala covid.

Hasil penelitian sebagian kecil responden memiliki pengetahuan kurang tentang pemeriksaan secara teratur sebanyak 8 responden $(18,6 \%)$. 
Sesuai kuesioner jawaban responden menunjukkan bahwa masih ada responden yang menjawab pernyataan salah terdapat pada nomor 5 sebanyak 6 responden (75\%) dengan pernyataan "Pemeriksaan kehamilan yang pertama kali sebaiknya dilakukan sesegera mungkin setelah diketahui terlambat haid". Hal ini karena untuk menjaga agar kehamilan sehat dan untuk mengevaluasi kondisi ibu dan janin selain itu juga penting untuk memantau tumbuh kembang janin serta mendeteksi adanya kelainan baik pada ibu maupun janin. Berdasarkan teori

Depkes (2006) menyatakan pemeriksaan kehamilan hendaknya dilakukan sedini mungkin dan secara rutin, hal ini berarti pemeriksaan kehamilan harus dilakukan segera setelah seorang wanita merasa dirinya hamil, agar pemberi pelayanan mempunyai waktu yang cukup untuk mengobati atau memperbaiki keadaan-keadaan yang akan menganggu kehamilan.

Hasil penelitian sebagian kecil responden memiliki pengetahuan baik tentang pemeriksaan kehamilan secara teratur sebanyak 2 responden $(4,7 \%)$.

Sesuai kuesioner jawaban responden yang menjawab pernyataan benar terdapat pada nomor 6 sebanyak 2 responden $(100 \%)$ dengan pernyataan "Pemeriksaan berat badan pada ibu hamil harus dilakukan untuk mengetahui kenaikan berat badan ibu sebelum dan saat hamil". Pernyataan ini benar,karena pemeriksaan berat badan harus dilakukan pada ibu hamil saat melakukan pemeriksaan kehamilan tujuannya untuk mengetahui kenaikan berat badan ibu hamil sebelum dan saat hamil apakah sudah cukup, kurang atau termasuk obesitas. Hal ini juga sesuai dengan teori Depkes RI \& JICA (2020) yang menyatakan bahwa pemeriksaan berat badan harus dilakukan agar mengetahui berapa jumlah kenaikan berat badan selama kehamilan apakah masih dalam batas normal atau tidak normal.total pertambahan BB pada kehamilan yang normal adalah $11,5-16 \mathrm{Kg}$.

2. Pengetahuan Ibu Hamil Tentang Tanda Bahaya Pada Kehamilan

Sesuai hasil kuesioner responden banyak menjawab penyataan benar terdapat pada pernyataan nomor 9 sebanyak 33 responden $(100 \%)$ dengan pernyataan "Perdarahan melalui jalan lahir pada kehamilan dapat membahayakan ibu dan janin" - perdarahan pada jalan lahir merupakan salah satu tanda bahaya pada kehamilan karena dapat mengancam keadaan ibu dan janin yang ada di dalam kandungan, perdarahan jalan lahir juga salah satu penyebab tingginya AKI \& AKB. Menurut Teori Depkes RI \& JICA (2020) Keluarnya darah dari jalan lahir sedikit atau banyak bisa disebabkan karena adanya plasenta previa, solusio plasenta, abortus, 
kehamilan mola dan kehamilan ektopik sehingga dapat membahayakan kesehatan ibu dan janin. Hasil penelitian sebagian kecil responden memiliki pengetahuan cukup tentang tanda bahaya pada kehamilan yaitu sebanyak 5 responden $(11,6 \%)$. Sesuai hasil kuesioner responden masih ada yang menjawab penyataan salah terdapat pada pernyataan nomor 15 sebanyak 4 responden (80\%) dengan pernyataan "Pandangan kabur secara mendadak pada ibu hamil akan mempengaruhi kesehatan ibu dan janin". Pandangan kabur secara mendadak merupakan tanda gejala dari preeklampsia berat. Teori dari Heffner \& Schust (2009) menyatakan bahwa tanda dan gejala preeklampsia berat yaitu tekanan darah $160 / 110 \mathrm{mmHg}$ atau lebih, pengeluaran protein dalam urine lebih dari $5 \mathrm{~g} / 24$ jam, teijadi penurunan produksi urine kurang dari $400 \mathrm{cc} / 25$ jam, terdapat edema paru dan sianosis (kebiruan) dan sesak napas, terdapat gejala subjektif (sakit kepa, gangguan penglihatan, dan nyeri di daerah perut atas).

Hasil penelitian sebagian kecil responden memiliki pengetahuan kurang tentang tanda bahaya pada kehamilan yaitu sebanyak 5 responden $(11,6 \%)$. Sesuai hasil kuesioner masih ada responden menjawab penyataan salah terdapat pada pernyataan nomor 14 sebanyak 5 responden (100\%) dengan pernyataan "Ibu hamil yang mengalami demam tinggi $>38^{\circ} \mathrm{C}$ dapat meningkatkan resiko kelainan pada janin seperti cacat", hal ini dikarenakan bisa saja adanya infeksi didalam tubuh ibu hamil sehingga menimbulkan tanda atau gejala suatu penyakit. Teori dari SDKI (2007) menyatakan bahwa ibu yang menderita demam dengan suhu tubuh $>38^{\circ} \mathrm{C}$ dalam kehamilan merupakan suatu masalah. Demam tinggi dapat merupakan gejala adanya infeksi dalam tubuh atau masuknya mikroorganisme pathogen ke dalam tubuh sehingga dapat mempengaruhi tumbuh kembang janin di dalam kandungan. Sejalan dengan penelitian A.A Rai, et al. (2020) dengan hasil penelitian menyatakan demam pada masa kehamilan ada hubungannya dengan kelahiran janin cacat. PenelitianSass (2017) menyatakan bahwa demam semasa kehamilan dapat membahayan perkembangan janin dan resiko lahir cacat. Pada studi yang dilakuakan di Denmark kepada 100,418 wanita hamil, menunjukkan bahwa 8,321 wanita melaporkan demam selama trimester pertama $(10,8 \%)$ dan 2.876 bayi didagnosis dengan kelainan bawaan $(3,7 \%)$.

3. Pengetahuan Ibu Hamil Tentang Perawatan Seharihari Ibu Hamil dan Porsi Makanan Ibu Hamil

Sesuai hasil kuesioner responden banyak menjawab 
penyataan benar terdapat pada pernyataan nomor 23 sebanyak 38 responden $(100 \%)$ dengan pernyataan "ibu hamil disarankan makan sayursayuran dan buah-buahan pada saat masa kehamilan", karena untuk membantu tumbuh kembang janin di dalam kandungan sehingga dapat meminimalisirkan teijadinya cacat. Teori dari Almatsier (2011) menyebutkan bahwa mengkonsumsi sayur dan buah sangat penting dilakukan ibu saat kehamilan untuk kesehatan ibu dan janin. Sayuran yang berwarna hijau dan jingga seperti bayam, wortel, tomat, serta buahbuahan berwma kuning jingga, seperti pepaya dan mangga, merupakan sumber vitamin A dalam bentuk pro vitamin $\mathrm{A}$ (karoten), vitamin C, dan asam folat yang sangat penting untuk kesehatan ibu dan janin.

Hasil penelitian sebagian besar responden memiliki pengetahuan cukup tentang Perawatan Sehari-hari ibu hamil dan makanan ibu hamil yaitu sebanyak 5 responden $(11,6 \%)$. Sesuai hasil kuesioner responden banyak menjawab penyataan salah terdapat pada pernyataan nomor 22 sebanyak 5 responden $(100 \%)$ dengan pernyataan "Ibu hamil disarankan keramas / cuci rambut lebih dari 2 hari sekali dalam seminggu". Ibu hamil disarankan untuk keramas setiap 2 dalam seminggu hal ini menjaga kebersihan rambut pada ibu hamil dan tidak membuat rambut ibu hamil menjadi kering karena terlalu sering keramas setiap hari. Selain itu juga untuk menghindari kerontokan pada rambut. Teori dari Depkes RI \& JICA (2020) menyatakan bahwa ibu hamil disarankan untuk keramas setiap 2x dalam seminggu agar dapat mengurangi hal-hal yang dapat memberikan efek negatif pada ibu hamil. Misalnya kerontokan, rambut menjadi kering karena dapat menhilangkan minyak alami dari yang tersisa dari rambut.

4. Gambaran pengetahuan Ibu Hamil Tentang Isi Buku KIA di Klinik Ramlah Paijib Kota Samarinda

Hasil Penlitian sebagian besar responden baik dipengaruhi karena faktor pendidikan responden yang menengah. Sesuai hasil penelitian bahwa responden dengan pendidikan menengah (SMA) sebanyak 30 maka responden dapat menerima dengan baik informasi yang diberikan oleh tenaga kesehatan. Menurut teori Ari ani (2014) mendukung dengan pernyataan bahwa semakin tinggi tingkat pendidikan seseorang semakin mudah orang tersebut menerima informasi. Pengetahuan erat hubungannya dengan pendidikan, seseorang dengan pendidikan yang menengah maka akan mudah menerima informasi yang diberikan baik dari tenaga kesehatan maupun dari media. Hal ini di dukung dengan penelitian Amelia, et al. (2016) ada hubungan pendidikan dan pengetahuan 
penggunaan buku kesehatan ibu dan anak (KIA) dengan hasil nilai $(\mathrm{p}$ value $)=0,013$ nilai koefisien korelasi Rank Spearman (r) sebesar 0,3.

Faktor Pengetahuan yang baik juga dipengaruhi oleh dan umur karena umur responden yang sudah matang. Hal ini sesuai dengan hasil penelitian bahwa reponden dengan umur 20-35 tahun sebanyak 30 responden $(100 \%)$. semakin cukup umur seseorang maka tingkat kematangan dalam berfikir akan lebih matang dan juga akan mempengaruhi daya tangkap sehingga pengetahuan dan pengalaman dalam berfikir akan lebih matang dan juga akan mempengaruhi daya tangkap. Sehingga pengetahuan dan pengalaman yang didapatkan akan semakin banyak dan baik. Teori Ari ani (2014), juga mendukung dengan pernyataan bahwa Jika seseorang itu memiliki umur yang cukup maka akan memiliki pola pikir dan pengalaman yang matang pula. Umur akan sangat berpengaruh terhadap daya tangkap sehingga pengetahuan diperolehnya akan semakin baik. Hal ini sejalan dengan penelitian Theresa, et al. (2018) hasil penelitian menunjukan, pemanfaatan buku KIA berdasarkan karakteristik usia berada pada usia 20-35 tahun sebanyak 82 orang $(54,3 \%)$ dengan pengetahuan baik.

Hasil penelitian sebagian kecil responden memiliki pengetahuan cukup sebanyak 13 responden $(30,2 \%)$ hal ini dipengaruhi karena faktor kurangnya informasi mengenai pemeriksaan kehamilan secara teratur Pengetahuan yang cukup dipengaruhi oleh kurangnya sumber informasi yang didapat oleh responden. Hal ini sesuai dengan hasil penelitian bahwa 13 reponden (100\%) kurang mendapatkan informasi dari petugas kesehatan baik dari bidan / dokter kandungan mengenai pemeriksaan kehamilan secara teratur. Sumber informasi sangat mempengaruhi pengetahuan sehingga diharapkan tidak ada responden yang tidak mengetahui tentang buku kia.

Berdasarkan Teori Ari ani (2014), juga mendukung dengan pernyataan bahwa seseorang yang memiliki sumber informasi yang lebih sedikit akan memiliki pengetahuan yang sempit. Sebaliknya jika seseorang memiliki sumbur informasi yang luas atau pemah mendapatkan informasi maka akan memiliki pengetahuan yang lebih luas. Salah satu sumber informasi yang berperan penting bagi pengetahuan yaitu informasi yang diberikan oleh petugas kesehatan baik bidan/dokter kandungan. Hal ini juga didukung dengan penelitian Cahyaningrum (2018), dengan hasil statistik nilai $\mathrm{p}$ value 0.034 sehingga dapat disimpulkan bahwa ada hubungan antara informasi dengan tingkat pengetahuan ibu

\section{SIMPULAN}


Gambaran Pengetahuan Ibu

Hamil tentang Isi Buku kia di Klinik Ramlah Paijib Kota Samarinda secara umum sebagian besar memiliki pengetahuan yang baik tentang isi buku KIA sebanyak 30 responden $(69,8)$.

Saran, Diharapkan pada peneliti selanjutnya dapat dijadikan sebagai bahan informasi hasil penelitian dan dapat dilanjutkan untuk diteliti lebih lanjut mengenai pemeriksaan kehamilan secara teratur yang saat ini masih belum banyak diketahui oleh ibu hamil dan anjuran ibu hamil agar membaca buku KIA.

\section{DAFTAR PUSTAKA}

Almatsier S, Soetardjo S, \& Soekatri M. (2011). Gizi Seimbang dalam Daur Kehidupan. Jakarta: PT Gramedia Pustaka Utama.

Ari ani, A.P. (2014). Aplikasi Meiodologi Pnelitian Kebidanan Dan Kesehaian Reproduksi. Yogyakarta: Nuha Medika.

Amelia Donsu, Sandra G J Tombokan, Agnes Montolalu, Dan Gusti Ayi Tirtawati. (2016). Hubungan Pendidikan Dan Pengetahuan Ibu Hamil Dengan Penggunaan Buku Kesehatan Ibu Dan Anak (KIA). Peneltian Buku KIA. Juli-Desember 2016. Vol. 4(2).

A. Wawan \& Dewi. (2010). Teori dan Pengukuran Pengetahuan, Sikap dan Perilaku Manusia. Yogyakarta: Nuha Medika

A. Aziz Alimul Hidayat \& Musrifatul Uliyah. (2012). Buku Ajar
Kebutuhan Dasar Manusia.

Surabaya: Health Books

Publishing

014). Buku Ajar Kebutuhan Dasar

Manusia. Surabaya: Health

Books Publishing

Budiman \& Riyanto. (2013). Kapita

Selekta Kuisioner

Pengetahuan dan Sikap Dalam

Penelitian Kesehatan. Jakarta:

Salemba Medika

Depkes RI \& JICA. (2020). Pelayanan antenatal. Jakarta:

EGC.

.(2015).Pelayanan

antenatal. Jakarta: EGC.

,(2012).Pelayanan

antenatal. Jakarta: EGC.

Depertemen RI. (2006).Pedoman Pelayanan Farmasi mituk Ibu Hamil dan Menyusui. Jakarta: Departemen Kesehatan RI.

Ernawati, F; Rosmalina, Y Dan Permanasari, Y. (2013). "Pengaruh Asupan Protein Ibu Hamil Dan Panjang Badan Bayi Lahir Terhadap Kejadian Stunting Pada Anak Usia 12 Bulan Di Kabupaten Bogor (Effect Of The Pregnant Women's Protein Intake And Their Baby Length At Birth To The Incidence Of Stunting Among Children Aged 12 Months In Bogor District)". Penelitian Gizi dan Makanan, Juni 2013 Vol. 36(1): 1-11

Gunawan, Imam. (2014). Metode Penelitian Kualitatif Teori dan 
Praktik. Jakarta: Bumi Aksara Manuaba, Ida Bagus Gde. (2013). Ilmu kebidanan, Penyakit Kandungan, dan KB. Jakarta: EGC

Nurul Hikmah Annis, Susilia Idayawati., Yadul Ulya. (2019).

HubunganPengetahuan Ibu Hamil dengan Kunjungn Antenatal Care di Wilayah Keija Pusesmas Sikur Kabupaten Lombok Timur.Universitas Ngudi Waluyo: Indonesian Journal of Midwifery (IJM)

Notoatmodjo, Soekidjo.(2018). Metode Penelitian Kesehatan. Jakarta: Rineka Cipta

\begin{tabular}{|c|}
\hline $\begin{array}{l}\text { Penelitian Kesehatan. } \\
\text { Rineka Cipta }\end{array}$ \\
\hline
\end{tabular}

------------------, (2012). Metode

Penelitian Kesehatan. Jakarta:

Rineka Cipta , (2010).Metode

Penelitian Kesehatan. Jakarta: - Rineka Cipta

Prawirohardjo Sarwono. (2014). Ilmu Kebidanan. Jakarta: Yayasan Bina Pustaka Sarwono Prawirohardjo.

Profil Kesehatan Provinsi Kalimantan Timur. (2016). Profil Kesehatan Provinsi
Kalimantan Timur:

Samarinda.

Sass L, Urhoj SK, Kjsergaard J, Dreier JW, Strandberg-Larsen $\mathrm{K}$, Andersen (2017), 'Fever in pregnancy and the risk of congenital malformations: a cohort study', BMC Pregnancy Childbirth, 17, pp.413

Sugiyono. (2012). Metode Penelitian Kuantitatif, Kualitatif, dan $R \& D$. Bandung: Alfabeta, $\mathrm{CV}$.

Saryono. (2011) Metodologi Penelitian Kesehatan. Jogjakarta: Mitra Cendika

Press Suryabrata, Sumadi. (2018). Metodologi Penelitian.

Depok: Raja Grafindo

Persada Swaijana, I. K.(2011). Metodelogi Penelitian Kesehatan. Yogyakarta:

Andi Offset Vamey, Helen. (2006). Buku Ajar Asuhan Kebidanan Edisi I. Jakarta : EGC

WHO. (2014). Angka Kematian Ibu dan Angka Kematian Bayi di Dunia. http://www.depkes.go.id/ resources/download/pusdatin/profilkesehatanindonesia/profil-kesehatanindonesia-2014.pdf 